\title{
Draining the swamp, or cultivating the wetlands? Toward evidence-based lobbying regulation and reform
}

\author{
Timothy M. LaPira' ${ }^{1}$ Thomas T. Holyoke ${ }^{2}$
}

(C) Macmillan Publishers Ltd 2017

Introduction to Interest Groups and Advocacy Special Issue on Lobbying Regulation and Reform (October 2017).

In his 2016 bid for the American presidency, Republican Donald Trump famously pledged to "drain the swamp" in Washington, DC. His pledge lacked a specific target, but it is hard to doubt he was taking aim at the system of special interests and lobbyists blamed by his populist followers for the perceived corruption in the capitol city. He was not even the first to use the catchy phrase. US House Minority Leader Nancy Pelosi (D-CA) said the same in the 2006 mid-term election to link then-majority Republicans to the infamous lobbyist Jack Abramoff's pay-toplay scandal. President Ronald Reagan described his 1984 campaign promise to break up captured regulatory bureaucracies as a mission to "drain the swamp".

While swamps may evoke images of insect infestation, malodor and unlivable conditions, most environmental scientists contend that "wetlands" are vital to healthy and diverse ecosystems of all kinds, even if they appear inhospitable. ${ }^{1}$ And likewise, beginning with James Madison's Federalist 10, many students of politics have argued that the interest group system-though flawed-is a natural and necessary consequence of representative government. We agree that the existing interest system is flawed in terms of the balance of competing interests and are concerned that existing ethical guidelines and regulations are insufficient to resolve the problem. We therefore conceived this special issue on lobbying regulation and reform to offer evidence of ways in which the sticky swamps of interest group politics might be remade into healthy democratic wetlands.

\footnotetext{
${ }^{1}$ We thank Lee Cronk for this apt analogy.

Timothy M. LaPira

lapiratm@jmu.edu

1 James Madison University, Harrisonburg, VA, USA

2 California State University, Fresno, Fresno, CA, USA
} 
Interest organizations and their lobbyists filter vast amounts of useful information to governments, just as wetlands filter water from shifting tides and seasonal floods. That is not to say the water we drink and bathe in is pure the moment it emerges from the wetlands, just as we could not say the information lobbyists provide to lawmakers solely promotes the common good. We can hardly blame the actual tidal swamps of the Anacostia River for dangerous levels of lead in US Capitol drinking water, nor should we condemn Washington's famous K Street for every unsavory idea that ends up in a bill in Congress. ${ }^{2}$ Indeed, many good ideas for policy come from interest groups, and many constituencies rely on interest groups for their political voice. It is as counterproductive to call for getting rid of the so-called special interests as it would be to eliminate wetlands.

Just as wetlands vary across climate, topography and hydrology, so too do interest group systems vary across political geographies and national boundaries. Accordingly, the objective of this special issue is to offer insight into the social scientific study of the causes, consequences and complications of lobbying regulation in a variety of political systems. The empirical research on lobbying regulation and reform we have compiled here offers insight into the emerging literature on how supranational institutions, nation-states and regional governments regulate organized interests' engagement in a variety of ways.

The articles in this issue differ in theoretical and methodological approaches, but share in common the neopluralist perspective on interest group politics (McFarland 2004; Lowery 2007). One article in this issue summarizes the complex and contingent nature of neopluralism especially nicely:

We would not expect pharmaceutical companies to ever publicly argue that they want to charge more simply to make more money for their executives and shareholders. It is up to advocates on the other side to make those arguments, and up to the companies to defend against them. This is the nature of public policy debate: All sides present their most convincing argument for why what they want is in the public interest. The best we can hope for is that out of a vibrant public discussion, only the most convincing and well-supported claims are left standing. Whatever the "real reasons" might be, what should matter at the end of the day is whether or not the policy can be justified on public interest grounds (Drutman and Mahoney 2017).

We hope this collection of articles advances a new and vigorous research agenda on the regulation of organized interests and lobbying and that these ideas and lessons help to improve democratic deliberation, interest representation and open governance around the world. More specifically, we hope that by improving our collective understanding of how lobbying works and how lobbying regulation may be improved, works in a variety of contexts may lead to innovative and effective political reforms in years to come.

\footnotetext{
${ }^{2}$ During the summer months of 2016, five drinking fountains in the Cannon House Office Building on Capitol Hill were found to have dangerously high levels of lead in the water (Bade 2016). As this issue goes to print, the Cannon Building is undergoing a roughly $\$ 750$ million renovation, part of which will make the building meet Environmental Protection Agency standards for healthy and safe working conditions (Architect of the Capitol 2017).
} 
The first two articles in this issue empirically explore how changes in both political context and in lobbying laws themselves affect interest groups' advocacy and lobbying behavior. Herschel Thomas and Timothy LaPira show that a recent decline in the number of registered lobbyists in Washington can be traced to a 2007 law intended to reform the 1995 Lobbying Disclosure Act (LDA). Though often thought to be the gold standard of lobbying regulation, the update to the LDA may have backfired by creating a gray market for lobbyists, rendering the law all but obsolete. The second article, by Adam Newmark, explores the multiple dimensions on which US states regulate lobbying and how some dimensions are emphasized over others across the states. This variation offers the possibility of examining which types of regulations are more or less effective. Different jurisdictions change lobbying regulations depending on how much their idiosyncratic political contexts allow them to expand (or contract) transparency and limit (or permit) certain influence behaviors.

Evidence of changes to existing lobbying regulations, then begs the question of why governments adopt new regulations, or reform old ones, at all. The next two articles offer new insight into the politics of changing lobbying regulation in Europe. Examining evidence from European Union member-state levels, Michele Crepaz suggests lobbying reforms are more likely to be placed on policy agendas in reaction to high profile scandals. However, counterintuitively, such scandals seemingly do not predict whether current lobbying regulation will change. These findings suggest that political reformers looking to the next big scandal to provide a window of opportunity for reform may be waiting in vain.

Jana Vargovčíková suggests that scandals themselves do not universally supply the impetus for reform, but rather that such change is dependent upon existing power relations between state and non-state actors. Using case studies of lobbying reform in Poland and the Czech Republic, this article highlights how the ability to change political relations between public and private actors depends on what each wants outside the domain of lobbying regulation. Those organized interests with greater stakes ex ante-especially in corporatist systems that assign private actors with some quasi-public policy authority-will seek to protect those stakes at the expense of others in any new lobbying regulation or transparency regime. Politicians themselves may embrace regulation in the aftermath of scandal, yet actively avoid transparency rules that would show the public just how closely policymakers and the "scandalous" interest groups work normally together. The question of lobbying regulation then is not simply whether there should be "more" or "better" regulation, but how established privileged interests and politicians gain and lose in the process.

The remaining two articles focus on innovative ways to understand what the fundamental problems of organized interests and lobbyists are. These articles recommend new ways of thinking about how to resolve these problems by leveraging advances in information technology and data analytics to improve lobbying transparency and policy deliberation. Thomas Holyoke focuses on the often-ignored ethical problem in lobbying: the principal-agent dilemma between clients and lobbyists. Laws like the LDA in the USA and the European lobbying registers are designed to expose interactions between organized interests and 
government officials, not between lobbyists and their clients. Yet it is precisely here where lobbyists may be most mischievous. Relatively uninformed clients have little way to monitor when, how and why their lobbyists may-rightly or wronglynegotiate policy positions away from their ideal policy preferences. He recommends that lobbying disclosure regimes include more sophisticated statements of policy positions.

Finally, Drutman and Mahoney take this concept a step further with their recommendation to "Post-Map-Ask" all public policy deliberations, including those policy positions that organized interest stakeholders seek. They advocate for a new data management system that lawmakers and legislative staff, lobbyists and advocates, journalists and watchdogs alike can manage and monitor for any given policy proposal. If organized interests are ideally suited to improve the quality of policy deliberations, then our transparency system ought to expose the substance of-not merely the existence of-lobbyists' activities.

Collectively, these articles are a significant step forward toward evidence-based lobbying regulation. Reforms based on superlatives about draining swamps are not likely to succeed if they do not consider the political and institutional contexts they are proposed to change. We trust that future meaningful efforts at political reform will instead seek to achieve the much more difficult task of preserving the deliberative democratic role that organized interests play, just as we ought to carefully cultivate our wetlands.

\section{References}

Architect of the Capitol. 2017. Cannon renewal project FAQs. https://www.aoc.gov/cannon/faqs. Viewed 18 May 2017.

Bade, S. 2016. House staffers could've been drinking lead-tainted water for months. Politico. http://www. politico.com/story/2016/06/house-capitol-tainted-water-224954. Viewed 18 May 2017.

Drutman, L., and C. Mahoney. 2017. On the advantages of a well-constructed lobbying system: Toward a more democratic, modern lobbying process. Interest Groups \& Advocacy. doi:10.1057/s41309-0170020-2.

Lowery, D. 2007. Why do organized interests lobby? A multi-context theory of lobbying. Polity 39 (1): 29-54.

McFarland, A.S. 2004. Neopluralism: The evolution of political process theory. Lawrence, KS: University Press of Kansas. 